\title{
Design of Ammonia Gas Measurement System using TGS-826 Sensor, Arduino Nano Microcontroller, 16x2 LCD, and Micro SD Module
}

\author{
Ach Junaidi, Frida Agung Rakhmadi*, Asih Melati, Kuwat Triyana. \\ Physics Department, Faculty of Science and Technology, State Islamic University of Sunan Kalijaga Yogyakarta. \\ Jl. Marsda Adisucipto, Yogyakarta, 55281 Telp : (0274) 512474, Fax : (0274) 586117 \\ Email*: frida.rakhmadi@uin-suka.ac.id
}

\begin{abstract}
Design of ammonia gas measurement system using TGS-826 sensor, Arduino Nano microcontroller, 16x2 LCD and micro SD module has been successfully carried out. Design was created with the help of SketchUp application. System design that has been made consists of ammonia adsorption chamber and electronic components in the form of a TGS-826 sensor, Arduino Nano microcontroller, $16 \times 2$ LCD and micro SD module. Working principle of the system that has been designed begins with the active sensor TGS-826 in detecting ammonia gas. Output from the sensor is then forwarded to the Arduino Nano microcontroller for processing. Processed data is then displayed by 16x2 LCD and the ammonia gas measurement data will automatically be stored in the micro SD module. Results of this design will make it easier in making the system.
\end{abstract}

Keyword : Ammonia; Electronic; System; Design.

\section{INTRODUCTION}

Ammonia is a chemical with a basic NH3 symbol, in the form of a gas which is very irritating, colorless, and has a very sharp odor (Hutabarat, 2007). Ammonia is often found in daily life such as in factory waste, toilets, chicken coops and so on. The presence of ammonia will easily interact with the air so that it will cause unpleasant odors. The emergence of ammonia gas will cause the environment to become unhealthy so that it interferes with the activity of living things around it. The presence of ammonia gas in the environment needs to be controlled so as not to cause undesirable things such as health problems and so on. One effort to control ammonia is by measuring the level of concentration or levels of ammonia gas. Ammonia has different levels of accuracy and will pose health hazards if humans inhale high concentrations of ammonia gas. The higher the concentration of ammonia gas, the higher the danger that will befall.

In general, spectrophotometer is used to measure the concentration of ammonia gas. But these measuring devices have very expensive prices. Therefore, it was made a measuring instrument that has a more affordable price. The measuring instrument is made with components in the form of TGS-826 sensor, Arduino Nano microcontroller, 16x2 LCD and micro SD module. In order to make the measurement possible optimally, it needs to be designed so that it will make it easier to make an ammonia gas measurement system.

\section{MATERIALS AND METHODS}

\section{Tools and materials}

There are several tools and materials that must be prepared during the system design process. The tools and materials are laptop and SketchUp application.

\section{Work procedures}

The making of ammonia gas measurement system design is carried out through three stages. The first stage is the preparation of tools and materials, then open the SketchUp application, and the final stage is to design the system. The three stages are explained in detail as follows.

a) In the first stage is preparing tools and materials that aim to prepare all kinds of tools and materials such as laptops and SketchUp applications. Tools and materials will help in the system design process so that it can run faster.

b) The second stage is opening the SketchUp application so the process of making the system design can be done. SketchUp application is an application that can make a building, such as houses, other buildings.

c) The final stage is to design a system that aims to create an image of the ammonia measuring instrument to be made. The target of making the system design is the creation of a system design image composed of ammonia adsorption chamber, TGS-826 sensor, Arduino Nano microcontroller, $16 \times 2$ LCD and micro SD module. 


\section{RESULTS AND DISCUSSION}

The design of the ammonia gas measurement system using the TGS-826 sensor and the Arduino Nano microcontroller has been successfully made as shown in Figure 2. In general, the design of the ammonia gas measurement system is divided into 2 parts, namely the ammonia adsorption chamber made of beaker glass and the enclosure chamber adsorption contained electronic components such as the TGS-826 sensor, Arduino Nano microcontroller, 16x2 LCD and micro SD module.

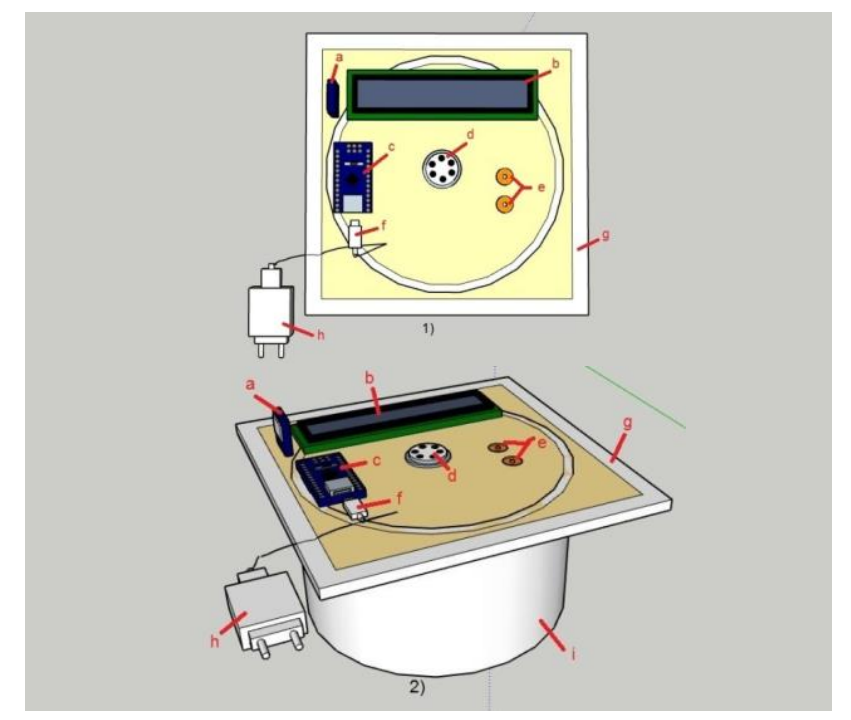

Information:
a. Micro SD module
f. USB
b. $16 \times 2$ LCD
g. Acrylic
c. Arduino Nano Microcontroller
d. Sensor TGS-826
e. Ammonia injection
h. Power supply
i. Beaker glass

Figure 1. System Design Results, 1) Side view, 2) Top view

When the power supply is on, the system will automatically start working according to their respective functions. Starting with the active sensor TGS-826 in detecting ammonia gas in the adsorption chamber. The output of the sensor in the form of resistance where the value will be lower when it detects ammonia gas with high concentrations (Saragih, 2008). The output is forwarded to the microcontroller for processing. Arduino Nano microcontroller reads the results from the TGS826 sensor and is displayed in the form of voltage (V). The formula determining the voltage value $(\mathrm{V})$ can be seen in equation 1.

Voltase $=\frac{\text { sensor value }}{A D C \text { total bits }} x$ analog voltage reference

The voltage reading $(\mathrm{V})$ is then converted to the ppm (part per million) value using equation 2

$$
\text { ppm }=X * \text { Voltase }
$$

where to determine the value of $\mathrm{x}$ using equation 3 (Susana et al, 2015).

$X=\frac{\text { range sensor }}{\text { ADC total bits }}$

The processed data results (ppm) are then displayed by a 16x2 LCD and automatically the ammonia gas measurement data will be stored in the micro SD module.

\section{CONCLUSION}

Design of ammonia gas measurement system using TGS-826 sensor, Arduino Nano microcontroller, 16x2 LCD and micro SD module has been successfully created with the help of SketchUp application. Working principle of the system that has been designed begins with the active sensor TGS-826 in detecting ammonia gas.

\section{ACKNOWLEDGEMENTS}

Acknowledgements to Mr. Kuwat Triyana and Mrs. Asih Melati for providing assistance in the form of ideas to the authors. The author also wishes to thank Mr. Frida Agung Rakhmadi who has helped in the process of making the journal to completion

\section{REFERENCES}

Figaro. 2004. TGS 826-For the Detection of Ammonia. USA. $\begin{array}{llll}\text { Diakses } & 27 & \text { Oktober } & 2019\end{array}$ dari http://www.figarosensor.com/products/docs/TGS\%20826 $\% 20 \% 2805 \_04 \% 29$.pdf.

Hutabarat, Olivia Imelda. 2007. Analisa Dampak Gas Amonia dan Klorin Pada FAAL Paru Pekerja Sarung Tangan Karet " $X$ ". (Thesis), Universitas Sumatera Utara. Medan.

Keeratirawee, Kanchalar. 2015. Coffee Residue-Based Adsorbent for Ammonia Removal from Aqueous Solution. International Conference on Advances in Agricultural, Biological \& Environmental Sciences. AABES 22-23 July 2015: 61-65.

Saragih, Christanty. 2018. Modifikasi Chamber dan Uji Coba Electronic Nose Pada Biji Kopi (Coffea sp). (Skripsi), Fakultas Pertanian Universitas Lampung. Bandar Lampung.

Susana Ratna, Nataliana Decy, Atiah Ummi. 2015. Sistem Monitoring Pendeteksi Kebocoran LPG Berbasis Mikrokontroler ATmega16 Menggunakan RF APC220. Jurnal ELKOMIKA. Vol. 2, No.2, Juli - Desember 2015: 191-211. 